Kathy Jackson $\quad$ ORCID iD: 0000-0002-0507-678X

\title{
Evaluation of dried blood spots for hepatitis B and D serology and nucleic acid testing.
}

\section{Running Title: DBS for HBV and HDV diagnostic testing}

*Kathy Jackson ${ }^{1}$, Thomas Holgate ${ }^{1}$, Rosemary Tekoaua ${ }^{2}$, Suellen Nicholson ${ }^{1}$, Margaret Littlejohn ${ }^{1}$ and Stephen Locarnini ${ }^{1}$.

${ }^{1}$ Victorian Infectious Diseases Reference Laboratory, Royal Melbourne Hospital and WHO Regional Reference Laboratory for Hepatitis B/D, at The Peter Doherty Institute for Infection and Immunity, Victoria, Australia

${ }^{2}$ Ministry of Health and Medical Services, Tungaru Central Hospital, Tarawa, Republic of Kiribati

*Corresponding Author

Email: kathy.jackson@mh.org.au

VIDRL, Doherty Institute, 792 Elizabeth Street, Melbourne, Australia 3000

\section{Acknowledgments:}

The authors wish to acknowledge Dr Alfred Tonganibeia from Tungaru central Hospital.

\begin{abstract}
Areas with the highest burden of hepatitis B virus (HBV) infection are often lowmiddle-income countries with limited access to diagnosis due to isolation, affordability and/or feasibility. Dried blood spots (DBS) provide an alternative for remote areas where collection and transportation of serum is impractical.

In this study the application of DBS for serological and molecular detection of HBV and hepatitis D virus (HDV) was evaluated.

HBsAg was detected in 87 of 91 (95.6\%) DBS. 17/21 (81\%) had detectable HBeAg and 52/71 (73.2\%) were anti-HBe positive. Anti-HD was detectable in

This is the author manuscript accepted for publication and undergone full peer review but has not been through the copyediting, typesetting, pagination and proofreading process, which may lead to differences between this version and the Version of Record. Please cite this article as doi: 10.1002/jmv.25485.
\end{abstract}

This article is protected by copyright. All rights reserved. 
11/12 (91.6\%) spiked control DBS after an initial failure to detect in patient DBS. HBV DNA was detected from 50/70 (71.4\%) DBS with serum loads greater than $200 \mathrm{IU} / \mathrm{mL}$ in an in-house assay and 18/24 (75\%) DBS with loads exceeding $389 \mathrm{IU} / \mathrm{mL}$ in a commercial assay. Using linear regression, HBV DNA loads from DBS were able to predict serum loads in 46 of 50 (92\%) samples to within 1 log of actual serum load. HDV RNA was detected in 42 of 47 (89\%) DBS with serum levels greater than $7,200 I U / m L$.

DBS are recommended for diagnosis of HBV, monitoring and detection of high loads in pregnant women where peripheral blood testing remains unfeasible. Detection of HDV RNA from DBS may prove useful in endemic areas.

\section{Key Words:}

Dried blood spots

Hepatitis B virus

Hepatitis D virus

Hepatitis B DNA load

Hepatitis B surface antigen

\section{Introduction}

Recent estimates suggest there are 292 million people worldwide chronically infected with hepatitis B virus (HBV) ${ }^{1}$ and $2-8 \%$ of those are also co-infected with hepatitis D virus (HDV) ${ }^{2}$. Furthermore the Global Burden of Disease Study reveals that viral hepatitis is a leading cause of death and disability and HBV and hepatitis C virus cause more than $90 \%$ of these cases ${ }^{3}$. The World Health Organisation (WHO) has launched a strategy to eliminate viral hepatitis as a major public health threat by $2030{ }^{4}$. One of the main challenges is to diagnose those infected so treatment and linkage to care can be achieved. Ironically for HBV, the areas with the greatest burden of disease are often low-middle-income countries (LMIC) ${ }^{5}$ with limited access to diagnostic support.

One of the main markers for diagnosis of $\mathrm{HBV}$ is detection of hepatitis $\mathrm{B}$ surface antigen (HBsAg), ${ }^{6}$. Point of care (POC) testing for HBsAg is available This article is protected by copyright. All rights reserved. 
and accessible in many LMIC. However follow-up serology and molecular testing on HBsAg positive samples is required to determine the phase, staging of infection and treatment eligibility. HBV DNA load testing is useful for these purposes but is currently not available as a POC test. HBV DNA testing often requires expensive instruments, diagnostic materials, maintenance, quality control and assurance, and technical expertise that are simply not available, affordable or feasible in many countries.

Dried blood spot (DBS) testing offers an alternative and/or complimentary approach to POC. DBS collection negates the need for venepuncture, cold storage and transportation, electricity supply and other necessities for collecting, preparing, storing and transporting serum for diagnostic testing. DBS can be stored and shipped at ambient temperature before subsequent processing. Ideally all the serological and molecular assays for HBV and/or HDV diagnosis could be performed at a central laboratory on the same DBS collection cards.

The republic of Kiribati is one of the most isolated places in the world. The population is spread over 33 islands that span 5 million square kilometres of the Pacific Ocean. HBV and HDV are endemic in Kiribati where the only available in-country HBV testing is HBsAg POC on the main island and capital, South Tarawa. Tenofovir for treatment of eligible HBV chronically infected people has recently become available. The Victorian Infectious Diseases Reference Laboratory (VIDRL), Australia is currently performing laboratory testing on sera collected at Tungaru Central Hospital (TCH). The laboratory support is enabling linkage to care, treatment and management of HBV and HDV. Transportation of samples from TCH to VIDRL was an initial stumbling block that was overcome by organising ambient shipments within 24 hours. As the Tenofovir-treatment program is expanded in Kiribati, blood collection from the outer, more remote islands becomes problematic. Hence a pilot study was established to evaluate and compare the use of DBS against paired serum for diagnosis of HBV and HDV. These results provide the basis for determining whether the estimation of HBV DNA load from DBS would prove

This article is protected by copyright. All rights reserved. 
beneficial for diagnosis, treatment monitoring and prevention of maternal to child transmission (MTCT).

\section{Materials and Methods}

Ethics Approval

Ethical approval for collection and testing of DBS for HBV and HDV markers was provided by the Kiribati Ministry of Health and Medical Services.

\section{Patient selection and serum samples}

Ninety-eight patients with a previous history of HBsAg positivity by POC testing (Alere Determine ${ }^{\mathrm{TM}} \mathrm{HBsAg}$, Waltham, Massachusetts) were recruited at Tungaru Central Hospital in 2017. Three or more DBS were collected on 2 different perforated filter paper cards manufactured by Munktell (TFN 12mm cards, Falun, Sweden) and Whatman (903 protein saver cards, Maidstone, United Kingdom) (figure 1) from finger/heel pricks. The DBS were allowed to dry for 2 or more hours and then stored for up to 6 months at $4^{\circ} \mathrm{C}$ in a sealed plastic envelope with desiccant. Matching serum was also collected and stored at $-80^{\circ} \mathrm{C}$ at TCH until shipping to VIDRL, Australia. DBS were stored for several months at $4^{\circ} \mathrm{C}$ at VIDRL before testing.

\section{Serology testing}

DBS controls were prepared as follows. One hundred and fifty microliters $(150 \mu \mathrm{l})$ whole blood was spiked with $150 \mu \mathrm{l}$ known antigen/antibodypositive serum and then $50 \mu \mathrm{l}$ was inoculated onto 6 filter paper spots. These were then dried and stored in a sealed plastic envelope with desiccant at $4^{\circ} \mathrm{C}$. Four disks from the Whatman DBS were punched from each sample and control and eluted in $900 \mu \mathrm{l}$ sterile phosphate-buffered saline (PBS) by shaking at room temperature for 15 minutes. Eluates were stored at $4^{\circ} \mathrm{C}$ overnight if not tested same day. After centrifugation the supernatants were analysed for HBsAg, HBeAg and anti-HBe on the LIAISON(® XL (Diasorin, Saluggia, Italy) and anti-HDV using ETI-AB-DELTAK-2 (anti-HD)(Diasorin, Saluggia, Italy). Matched sera were tested on the same platforms as the DBS. After an initial poor sensitivity with the anti-HD assay was achieved, a

This article is protected by copyright. All rights reserved. 
subsequent set of controls was prepared with 12 anti-HD-positive patient sera ( 6 with detectable and 6 non-detectable HDV RNA). Fifty $\mu$ l of serum was mixed with $50 \mu \mathrm{l}$ blood and then $75 \mu \mathrm{l}$ inoculated onto the Whatman perforated cards, allowed to dry and then stored in a sealed plastic envelope with desiccant at $4^{\circ} \mathrm{C}$ for 10 days. A whole perforated spot was resuspended in $300 \mu$ PBS overnight with intermittent vortexing before testing for antiHD.

\section{Molecular Testing}

DBS HBV DNA controls were prepared as follows. Ten-fold dilutions of a known positive serum sample with resulting 10 -fold loads of $6.9 \log _{10} \mathrm{IU} / \mathrm{mL}$ down to $0.09 \log _{10} \mathrm{IU} / \mathrm{mL}$ were mixed with equal volumes of uninfected blood. Fifty microlitres and $75 \mu \mathrm{l}$ of each dilution were inoculated onto perforated Munktell cards, allowed to dry for 2 hours, then placed in plastic envelopes with dessicant and stored at $4^{\circ} \mathrm{C}$ for 2 weeks. The 2 different inoculum sizes were used to simulate the volume of blood spotted in practice. These controls and 71 patient DBS were then prepared for HBV load testing as follows. One whole perforated spot was punched from the Munktell cards and placed in a tube containing $180 \mu \mathrm{l}$ tissue lysis buffer (ATL) from QIAamp DNA Mini Kit as recommended by the manufacturers (Qiagen, Hilden, Germany). This was incubated at $95^{\circ} \mathrm{C}$ for 15 minutes before addition of $20 \mu \mathrm{l}$ Proteinase $\mathrm{K}$ and a further incubation at $56^{\circ} \mathrm{C}$ for 1 hour. QIAamp lysis buffer $(\mathrm{AL})(200 \mu \mathrm{l})$ was added and further incubated at $56^{\circ} \mathrm{C}$ for 10 minutes. DNA was then extracted as per manufacturer's instructions. The DNA from these DBS were then analysed for HBV DNA load using an in-house Taqman probe assay adapted from the method described by Sitnik et al ${ }^{7}$ and validated against the WHO HBV DNA standards in order to report in IU/mL. Twenty four DBS were also prepared for DNA extraction and HBV DNA load analysis on the Abbott RealTime HBV Viral Load Assay (Illinois, US). Specifically, each DBS was added to $600 \mu \mathrm{l}$ Abbott lysis buffer, vortexed, incubated overnight at room temperature, and then centrifuged. Paired serum samples from each of the DBS and the DBS supernatants were assayed in the RealTime HBV Viral Load Assay (Illinois, US) following manufacturer's methodology.

This article is protected by copyright. All rights reserved. 
HBV DNA was also extracted and tested in the in-house assay from 47 Munktell DBS (from 47 individuals) more than one year after collection and storage at $4^{\circ} \mathrm{C}$ to determine the long-term stability of the HBV DNA in DBS. A further 6 Whatman DBS that had been stored at $4^{\circ} \mathrm{C}$ for more than 1 year old were tested together with paired Munktell cards from above.

HDV RNA DBS controls were prepared in a similar manner to the HBV DNA controls using ten-fold dilutions of a known HDV RNA positive serum with resulting range of viral loads of $7.4 \log _{10} \mathrm{IU} / \mathrm{mL}$ to $0.4 \log _{10} \mathrm{IU} / \mathrm{mL}$. Extraction of HDV RNA from the control DBS and forty-one patient Munktell DBS (that had HDV RNA detected in the paired serum) was then attempted as follows. One whole perforated spot was added to $560 \mu \mathrm{l}$ QIAamp RNA lysis buffer (Qiagen, Hilden, Germany) and $140 \mu$ negative serum. The DBS were incubated at room temperature for 30 minutes with occasional voretxing, then RNA was extracted as per the QIAamp RNA mini kit manufacturer's instructions.

HDV RNA was also extracted from 12 DBS from paired Whatman filter paper cards to determine if there was any variability between the Munktell and Whatman cards. To determine whether a total nucleic acid extraction method (which could theoretically simultaneously extract HBV DNA and HDV RNA), an extraction of HDV RNA was also attempted from six DBS using the Qiagen MinElute PCR purification kit (Qiagen, Hilden, Germany). Briefly, the DBS were resuspended in $200 \mu \mathrm{l}$ normal saline, then incubated at $56^{\circ} \mathrm{C}$ with proteinase $\mathrm{K}$ and lysis buffer, as per manufacturer's instructions for plasma and serum, before purifying on the MinElute columns. RNA from paired serum samples was extracted using the QIAamp RNA mini kit. All DBS and serum samples were heat-shocked at $95^{\circ} \mathrm{C}$ for 5 minutes to relax the secondary structure, cooled on ice, then reverse-transcribed before quantifying HDV RNA using a LightCycler-based FRET-probe PCR assay as previously described ${ }^{8,9}$. Briefly the relaxed RNA was reverse transcribed using SuperScript ${ }^{\mathrm{TM}}$ VILO $^{\mathrm{TM}}$ cDNA Synthesis Kit (Invitrogen, CA, USA) by incubating at $42^{\circ} \mathrm{C}$ for 1 hour before inactivating at $80^{\circ} \mathrm{C}$ for 10 minutes. The cDNA was then quantitated on the LightCycler (Roche Diagnostics,

This article is protected by copyright. All rights reserved. 
Mannheim, Germany) using primers, probes and conditions described by Schaper et $\mathrm{al}^{9}$. Plasmid pDL445 containing an $843 \mathrm{bp}$ fragment of the HDV genome and known copy number was used as a standard. The assay was standardised against the WHO HDV standard enabling expression of results in $\mathrm{IU} / \mathrm{mL}$.

\section{Statistical analysis}

Correlation and trend-lines were calculated in Microsoft Excel 2010.

\section{Results}

\section{Hepatitis $B$ and D Serology results}

The results of the serological testing from the DBS and matching sera are summarized in Table 1. Four DBS samples that had matched detectable serum HBsAg were found to be undetectable for HBsAg. The inability to detect HBsAg in these samples was unrelated to the matched serum levels, which were between 79 and $2973 \mathrm{IU} / \mathrm{mL}$. Twenty-four serum samples, with levels below $2973 \mathrm{IU} / \mathrm{mL}$ and as low as 9, were detected in DBS. These 4 HBsAg negative DBS samples had DNA load levels that were all positive but below $99 \mathrm{IU} / \mathrm{mL}$. Four DBS from HBeAg positive individuals also had undetectable HBeAg. These 4 samples had low levels of HBeAg in serum < 0.7 PEIU/mL. Detection of anti-HBe from DBS proved less reliable with only $73.2 \%$ positive serum samples having detectable anti-HBe in DBS. Detection of antibodies to HDV was also unreliable with all 13 patient DBS samples tested failing to yield detectable anti-HD. However, when a whole spot was dedicated to anti-HD testing, 11/12 (91.6\%) spiked control samples had detectable antibody.

\section{Hepatitis B Molecular Virology results}

HBV DNA was detected in the in-house assay in 50 DBS from 70 (71.4\%) individuals with HBV DNA detected in serum. A 71st DBS from a serum HBV DNA negative individual was used as a "negative control" for crosscontamination. All 21 DBS with undetectable HBV DNA had serum levels below $200 \mathrm{IU} / \mathrm{mL}$ including the undetectable "negative control". 24 DBS

This article is protected by copyright. All rights reserved. 
tested in the Abbott RealTime assay were compared with the internally validated HBV DNA assay ${ }^{7}$. Sixteen samples were detected as reactive in both assays. Three samples were detected in the in-house assay alone and two in the Abbott assay only. The DBS limit of detection (LOD) in the Abbott assay in this study was $>389 \mathrm{IU} / \mathrm{mL}$. Importantly, with both assays all samples with HBV DNA loads $>400 \mathrm{IU} / \mathrm{mL}$ were detected in DBS. The correlation between the DBS HBV DNA load from the in-house assay and serum load is shown in figure 2. Overall the results showed a 96.3\% correlation.

HBV DNA controls' cycle thresholds (Ct's) were also plotted against the known inoculated load, (figure 3). The different inoculum sizes of 50 and $75 \mu \mathrm{L}$ were assigned the same $\log _{10}$ value to allow for variation in patient DBS volumes that are estimated to be between 50 and $75 \mu$ l. The equation of the trend-line $(y=-2.9906 x+43.239)$ was then used to estimate the serum load ( $\mathrm{x}$ value) by using the Ct value of the patient DBS as the y intercept. In this way 46 of 50 (92\%) DBS were accurately used to predict a viral load within 1 $\log$ of the actual serum load. The average difference between the actual serum load and predicted load was $0.03 \log _{10} \mathrm{IU} / \mathrm{mL}$. Two of the 4 aberrant predictions were 1.2 and $1.6 \log _{10} \mathrm{IU} / \mathrm{mL}$ higher than the actual serum levels, which were 6.99 and $7.22 \log _{10} \mathrm{IU} / \mathrm{mL}$ respectively. The other 2 aberrations were underestimates of samples with viral loads $<400 \mathrm{IU} / \mathrm{mL}$.

Processing and testing a second spot more than 1 year after collection assessed the stability of HBV DNA in the DBS. HBV DNA was detected in 42 of 47 (89\%) DBS that were initially positive. The paired serum viral loads for the negative DBS were all below $163 \mathrm{IU} / \mathrm{mL}$. There was an excellent correlation of $99.7 \%$ between the Ct's of the 6 matching 1 year-old Munktell and Whatman DBS. To determine whether the serum viral loads could still be predicted from the 1 year-old DBS, the Ct's were inserted into the equation. $36(86 \%)$ of 42 positive DBS estimated a viral load within $1 \log _{10}$ of the actual serum load. Two DBS overestimated high viral load samples over 7 $\log _{10} \mathrm{IU} / \mathrm{mL}$. The 4 DBS that inaccurately under-predicted the actual serum load had serum levels below $465 \mathrm{IU} / \mathrm{mL}$ HBV DNA.

This article is protected by copyright. All rights reserved. 
Hepatitis D RNA results

HDV RNA was detected in all the RNA control DBS with a $2.4 \log _{10} \mathrm{IU} / \mathrm{mL}$ or higher but only in the DBS inoculated with $75 \mu \mathrm{l}$ of 1.4 and $0.4 \log _{10} \mathrm{IU} / \mathrm{mL}$ HDV RNA. HDV RNA was detected in 42 of 47 (89\%) DBS from 35 patients with paired serum positivity. The serum RNA loads in the undetectable DBS were all below 7,200 IU/mL (3.8 $\left.\log _{10} \mathrm{IU} / \mathrm{mL}\right) .2$ DBS with serum levels below this (3.3 and $3.5 \log _{10} \mathrm{IU} / \mathrm{mL}$ ) were however detectable. The correlation between the Munktell and Whatman filter paper cards was excellent at $98.4 \%$.

\section{Discussion}

Dried blood spots have been used as an alternative to peripheral blood, serum or plasma for decades for the diagnosis and detection of HBV infectious markers 10,11. Despite the technical advances in molecular diagnostics over the last 2-3 decades DBS still have a pivotal role to play in LMIC and remote areas. Initial studies described their use in serological testing of HBV and later quantification and sequencing of HBV DNA ${ }^{10,12,13}$. To our knowledge there have been no reports describing the use of DBS for HDV diagnosis. This study however details the comprehensive evaluation of DBS for HBV and HDV serological and molecular testing in a real-world population in one of the most remote areas of the world, Kiribati.

The results shown here confirm the potential of estimating serum HBV DNA viral loads from DBS by linear regression (figure 3) with great accuracy and sensitivity. Whether the in-house (figure 2) or Abbott commercial assay was used, DNA could be detected in patient DBS with a limit of detection (LOD) of around 200 or $400 \mathrm{IU} / \mathrm{mL}$ respectively. The $200 \mathrm{IU} / \mathrm{mL}$ LOD was comparable with another study by Mossner et al ${ }^{14}$ but generally superior to several other studies where LOD of 914, $1215 \mathrm{IU} / \mathrm{mL}$ or higher were recorded 12,15,16. Despite only testing small numbers, Stene-Johansen et al reported a LOD of $500 \mathrm{IU} / \mathrm{mL}$ in DBS tested on the Abbott RealTime assay which is comparable to the $400 \mathrm{IU} / \mathrm{ml}$ described here. The LOD may have been superior in this

This article is protected by copyright. All rights reserved. 
study as whole perforated spots were used for molecular analysis instead of punched spots.

By employing the gradient equation 92\% DBS could be used to accurately determine the serum load to within $1 \log _{10}$ of the actual level. The inaccuracies in the estimations occurred at either the upper or lower limits of load determination suggesting all mid-range load determinations were fairly accurate. These results could reliably guide treatment decisions based on the EASL ${ }^{17}$, AASLD 18 and/or APASL ${ }^{19}$ guidelines and be used to predict high viral load mothers $(>200,000 \mathrm{IU} / \mathrm{mL})$ at risk of MTCT without antiviral intervention.

The in-house HBV DNA assay described here and adapted from that published by Sitnik et al ${ }^{7}$, could also be performed in LMIC with molecular capacity without the need for expensive commercial platforms. The HBV DNA load results are comparable with those of the Abbott RealTime HBV assay (showing 96.3\% correlation) and when used with DBS, may provide feasibility of load testing for remote areas. Several studies describe the stability of HBV DNA in DBS over days, weeks to months 10,11,13,15. Here we document minimal loss of HBV DNA (11\% samples and all under $163 \mathrm{IU} / \mathrm{mL}$ ) and no change to the LOD after 12 months of storage at $4^{\circ} \mathrm{C}$. In addition, the serum viral loads could still be reasonably accurately predicted from these 1 year-old DBS.

Unfortunately this study did not assess storage of DBS at room temperature, which may more accurately reflect storage conditions in remote areas. The DBS were however transported at room temperature with apparent minimal loss of biomarkers. Further studies may be required to fully assess the effect of long-term room temperature storage.

Previous studies have shown that HBsAg can be reliably detected from DBS with sensitivities of $96.5 \%$ and $98.6 \%$ respectively ${ }^{14,20}$. This study also reveals that employment of DBS for initial screening and determination of exposure to HBV by HBsAg detection was feasible and extremely accurate with $95.6 \%$ sensitivity and $100 \%$ specificity (Table 1). Samples with paired This article is protected by copyright. All rights reserved. 
serum HBsAg levels as low as $9 \mathrm{IU} / \mathrm{mL}$ were detected. There were 4 DBS where HBsAg could not be detected; these were unrelated to the HBsAg level in serum, which ranged from to 79 - $2973 \mathrm{IU} / \mathrm{mL}$, and may reflect inadequate DBS collection or sampling. Ross et $\mathrm{al}^{20}$ also found discrepant results between sera and DBS with HBsAg levels of 749 and $6 \mathrm{IU} / \mathrm{mL}$. The $4 \mathrm{HBsAg}$ negative DBS detailed here were from individuals with low viral loads (under $100 \mathrm{IU} / \mathrm{mL}$ ) who would not be eligible for HBV treatment without clinical indications.

Although the numbers were small, detection of HBeAg from DBS was also reasonably accurate in samples with serum levels over 7 PEIU $/ \mathrm{mL}$. Disappointingly, anti-HBe was only detected in 73.2\% DBS samples with positive serum. Other publications describing assaying anti-HBe from DBS are scarce. Studies by Ross et $\mathrm{al}^{20}$ and Zimmermann et $\mathrm{a}^{21}$ demonstrated detection rates of alternative anti-bodies to $\mathrm{HBV}$, anti-HBc; with resulting sensitivities of $86.3 \%$ and $94.3 \%$ respectively, and anti-HBs; with sensitivities of $94.3 \%$ and $80 \%$ respectively. Ross et $a^{20}$ reveal that the discrepant results between serum and DBS for anti-HBs are likely due to low levels (11-26 IU/mL). A comparison cannot be made here, as the qualitative anti-HBe assay employed did not yield quantitative results.

Anti-HD detection in patient DBS initially proved insensitive in this study. However after resuspending a whole dedicated spot in a smaller volume (300 $\mu \mathrm{l}$ ), 11/12 spiked samples had detectable anti-HDV This result was encouraging as screening for exposure to HDV in the Kiribati population is important due to its endemicity. The authors here recommend testing of HBsAg-positive samples for anti-HD and reflexing positives into a HDV RNA assay ${ }^{8}$. If DBS are examined, dedicating a whole spot for anti-HD determination should be considered. Detection of HDV RNA from DBS was reasonablysuccessful with $89 \%$ sensitivity although the limit of detection in this study is only around $3.8 \log _{10} \mathrm{IU} / \mathrm{mL}$. The low sensitivity may be improved by shortening the storage interval. For logistical reasons the DBS in this study may have been stored for up to 6 months before processing. Although small numbers were tested, comparison of the Whatman and This article is protected by copyright. All rights reserved. 
Munktell filter cards revealed no difference in detection of HDV RNA (98.4\% correlation) and HBV DNA (99.7\% correlation).

As previous authors have reported ${ }^{13}$ detection of HBV markers from DBS is not recommended for blood transfusion screening. However DBS are highly recommended for the initial diagnosis of HBV and HDV infection, determination of treatment eligibility and monitoring, and detection of high viral loads in pregnant women in areas of the world where collection, transportation and testing of peripheral blood remains unfeasible.

Table

Table 1: Comparison of serology results for DBS with paired sera.

\begin{tabular}{|c|c|c|c|c|c|c|}
\hline Derum & $\begin{array}{c}\text { HBsAg } \\
\text { detected }\end{array}$ & $\begin{array}{c}\text { HBsAg } \\
\text { not } \\
\text { detected }\end{array}$ & $\begin{array}{c}\text { HBeAg } \\
\text { detected }\end{array}$ & $\begin{array}{c}\text { HBeAg } \\
\text { not } \\
\text { detected }\end{array}$ & $\begin{array}{c}\text { anti-HBe } \\
\text { detected }\end{array}$ & anti-HBe \\
not \\
detected
\end{tabular}

This article is protected by copyright. All rights reserved. 


\begin{tabular}{|c|c|c|c|c|}
\hline $\begin{array}{l}\text { HBeAg } \\
\text { detected }\end{array}$ & $\begin{array}{l}17 / 21 \\
(80.9)\end{array}$ & $\begin{array}{c}4 / 21 \\
(19.0)\end{array}$ & & \\
\hline $\begin{array}{c}\text { HBeAg } \\
\text { not } \\
\text { detected }\end{array}$ & & $\begin{array}{l}77 / 77 \\
(100)\end{array}$ & & \\
\hline $\begin{array}{l}\text { anti-HBe } \\
\text { detected }\end{array}$ & & & $\begin{array}{l}52 / 71 \\
(73.2)\end{array}$ & $\begin{array}{l}19 / 71 \\
(26.8)\end{array}$ \\
\hline $\begin{array}{l}\text { anti-HBe } \\
\text { not } \\
\text { detected }\end{array}$ & & & & $\begin{array}{l}27 / 27 \\
(100)\end{array}$ \\
\hline
\end{tabular}

Biomarker analysed for DBS is shown in the column headings. Biomarker analysed for serum is shown in the row heading. Data in green represents agreed result between paired DBS and serum. Data shown in red indicates discrepancy between DBS and serum result.

* Figures in parentheses represent percentages.

\section{References}

1. Razavi-Shearer D, Razavi H. Global prevalence of hepatitis B virus infection and prevention of mother-to-child transmission - Authors' reply. The lancet. Gastroenterology \& hepatology. Sep 2018;3(9):599.

2. Wranke A, Pinheiro Borzacov LM, Parana R, et al. Clinical and virological heterogeneity of hepatitis delta in different regions worldwide: The Hepatitis Delta International Network (HDIN). Liver

This article is protected by copyright. All rights reserved. 
international : official journal of the International Association for the Study of the Liver. May 2018;38(5):842-850.

3. Stanaway JD, Flaxman AD, Naghavi M, et al. The global burden of viral hepatitis from 1990 to 2013: findings from the Global Burden of Disease Study 2013. Lancet. Sep 10 2016;388(10049):1081-1088.

4. Organization WH. Global health sector strategy on viral hepatitis, 2016-2021: Towards ending viral hepatitis. http://www.who.int/hepatitis/strategy2016-2021/ghss-hep/en/. 2016;WHO reference number: WHO/HIV/2016.06:1-56.

5. Allain JP, Opare-Sem O. Screening and diagnosis of HBV in low-income and middle-income countries. Nature reviews. Gastroenterology \& hepatology. Nov 2016;13(11):643-653.

6. Jackson K, Locarnini S, Gish R. Diagnostics of Hepatitis B Virus: Standard of Care and Investigational. Clin Liv Dis. 2018;in press.

7. Sitnik R, Paes A, Mangueira CP, Pinho JR. A real-time quantitative assay for hepatitis B DNA virus (HBV) developed to detect all HBV genotypes. Revista do Instituto de Medicina Tropical de Sao Paulo. MayJun 2010;52(3):119-124.

8. Jackson K, MacLachlan J, Cowie B, et al. Epidemiology and phylogenetic analysis of hepatitis D virus infection in Australia. Internal medicine journal. May 142018.

9. Schaper M, Rodriguez-Frias F, Jardi R, et al. Quantitative longitudinal evaluations of hepatitis delta virus RNA and hepatitis B virus DNA shows a dynamic, complex replicative profile in chronic hepatitis $B$ and D. Journal of hepatology. May 2010;52(5):658-664.

10. Jardi R, Rodriguez-Frias F, Buti M, et al. Usefulness of dried blood samples for quantification and molecular characterization of HBVDNA. Hepatology. Jul 2004;40(1):133-139.

11. Lira R, Maldonado-Rodriguez A, Rojas-Montes 0 , et al. Use of dried blood samples for monitoring hepatitis B virus infection. Virology journal. Sep 29 2009;6:153.

12. Mohamed S, Raimondo A, Penaranda G, et al. Dried blood spot sampling for hepatitis B virus serology and molecular testing. PloS one. 2013;8(4):e61077.

13. Stene-Johansen K, Yaqoob N, Overbo J, et al. Dry Blood Spots a Reliable Method for Measurement of Hepatitis B Viral Load in ResourceLimited Settings. PloS one. 2016;11(11):e0166201.

14. Mossner BK, Staugaard B, Jensen J, Lillevang ST, Christensen PB, Holm DK. Dried blood spots, valid screening for viral hepatitis and human

This article is protected by copyright. All rights reserved. 
immunodeficiency virus in real-life. World journal of gastroenterology. Sep 7 2016;22(33):7604-7612.

15. Lange $B$, Cohn J, Roberts $T$, et al. Diagnostic accuracy of serological diagnosis of hepatitis $C$ and $B$ using dried blood spot samples (DBS): two systematic reviews and meta-analyses. BMC infectious diseases. Nov 1 2017;17(Suppl 1):700.

16. Vinikoor MJ, Zurcher S, Musukuma K, et al. Hepatitis B viral load in dried blood spots: A validation study in Zambia. Journal of clinical virology : the official publication of the Pan American Society for Clinical Virology. Nov 2015;72:20-24.

17. EASL 2017 Clinical Practice Guidelines on the management of hepatitis B virus infection. Journal of hepatology. Aug 2017;67(2):370398.

18. Terrault NA, Lok ASF, McMahon BJ, et al. Update on prevention, diagnosis, and treatment of chronic hepatitis B: AASLD 2018 hepatitis B guidance. Hepatology. Apr 2018;67(4):1560-1599.

19. Sarin SK, Kumar M, Lau GK, et al. Asian-Pacific clinical practice guidelines on the management of hepatitis B: a 2015 update. Hepatology international. Jan 2016;10(1):1-98.

20. Ross RS, Stambouli O, Gruner N, et al. Detection of infections with hepatitis $B$ virus, hepatitis $C$ virus, and human immunodeficiency virus by analyses of dried blood spots--performance characteristics of the ARCHITECT system and two commercial assays for nucleic acid amplification. Virology journal. Mar 5 2013;10:72.

21. Zimmermann R, Marcus U, Schaffer D, et al. A multicentre serobehavioural survey for hepatitis B and C, HIV and HTLV among people who inject drugs in Germany using respondent driven sampling. $B M C$ public health. Aug 14 2014;14:845.

This article is protected by copyright. All rights reserved. 


\section{Figures}

Figure 1: Munktell (upper panel) and Whatman (lower panel) cards with perforated spots used in this study.

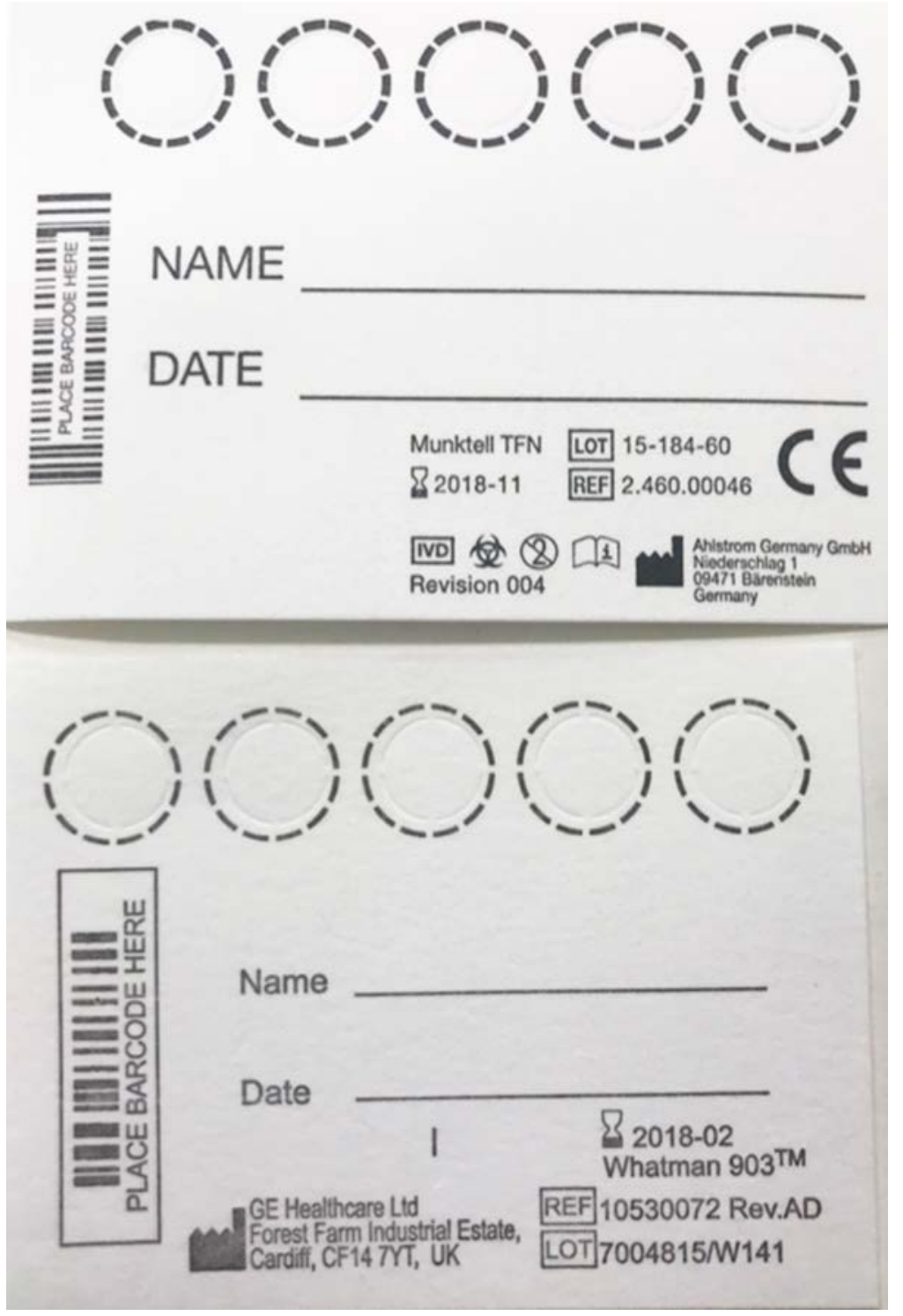

This article is protected by copyright. All rights reserved. 
Figure 2: Correlation between the DBS in-house HBV DNA load results and the serum load results (Abbott m2000). The coefficient of determination, R2 is 0.96278

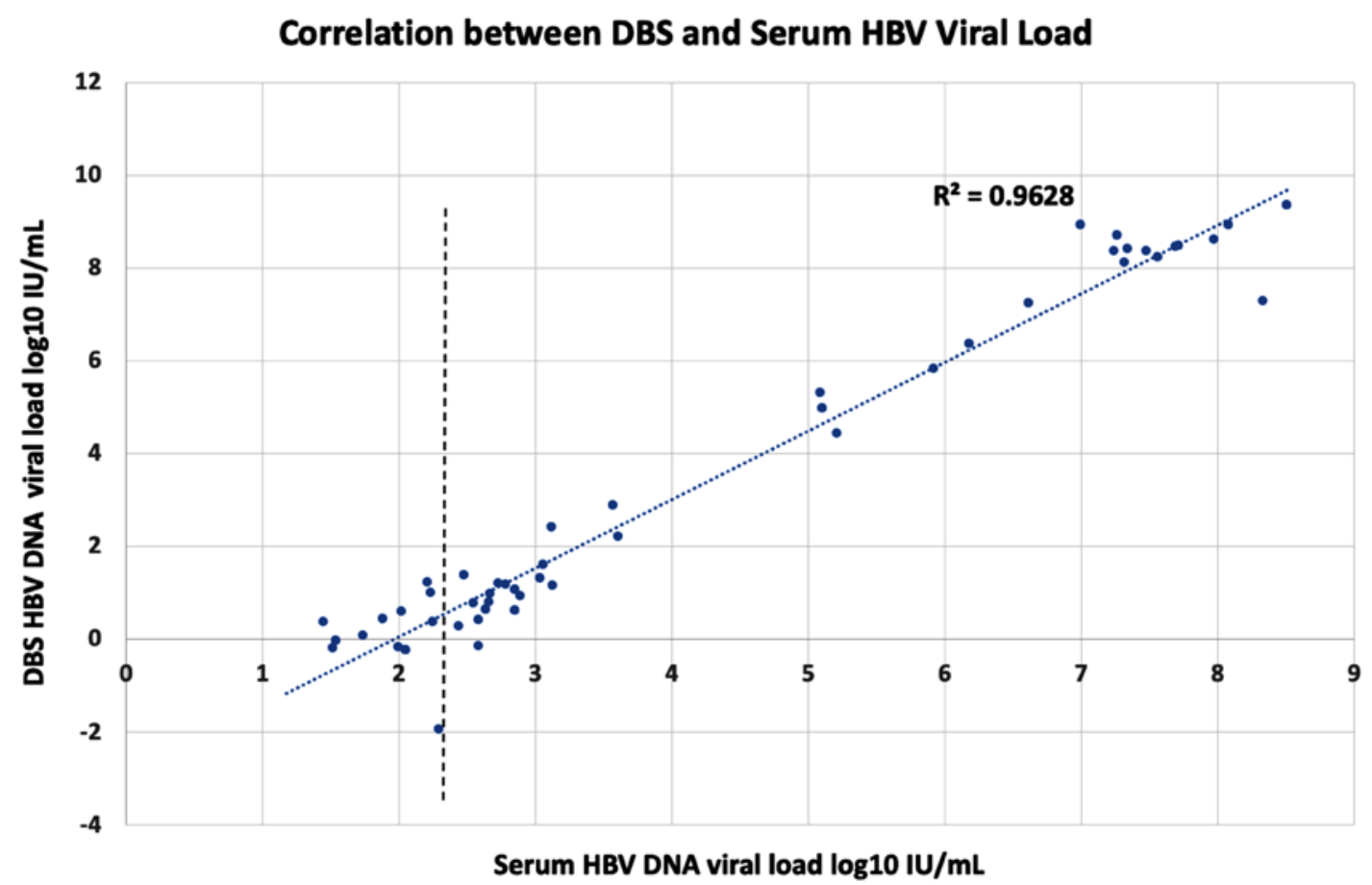

Figure 3: Plot of cycle threshold (Ct) of the spiked HBV DNA controls against the known starting $\log _{10} \mathrm{IU} / \mathrm{mL}$. The results of inoculum sizes, $50 \mu \mathrm{l}$ and $75 \mu \mathrm{l}$, were used to account for the variability in DBS volumes.

\section{Spiked HBV DNA load v/s Ct}

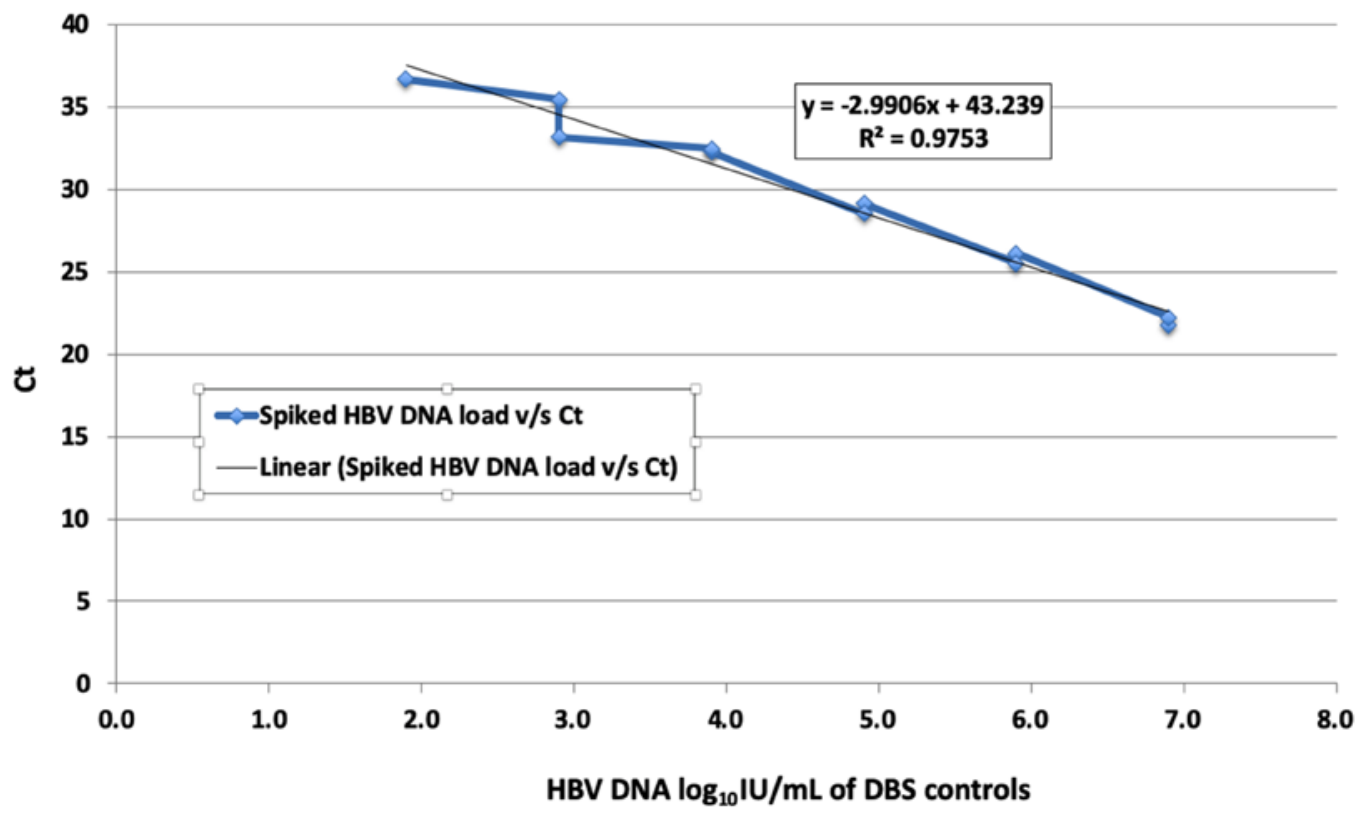

This article is protected by copyright. All rights reserved. 


\section{University Library}

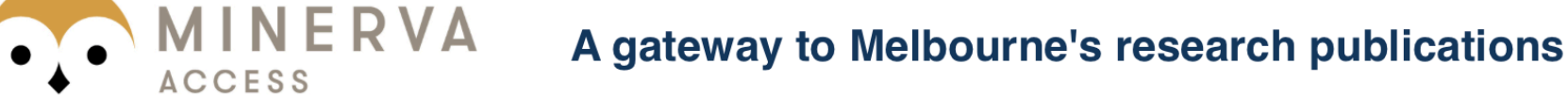

Minerva Access is the Institutional Repository of The University of Melbourne

\section{Author/s:}

Jackson, K;Holgate, T;Tekoaua, R;Nicholson, S;Littlejohn, M;Locarnini, S

Title:

Evaluation of dried blood spots for hepatitis B and D serology and nucleic acid testing

Date:

2022-02-01

Citation:

Jackson, K., Holgate, T., Tekoaua, R., Nicholson, S., Littlejohn, M. \& Locarnini, S. (2022).

Evaluation of dried blood spots for hepatitis B and D serology and nucleic acid testing.

JOURNAL OF MEDICAL VIROLOGY, 94 (2), pp.642-648. https://doi.org/10.1002/jmv.25485.

Persistent Link:

http://hdl.handle.net/11343/285731 